\title{
A munkaerőhiány néhány kérdése a közép-magyarországi régióban - empirikus vizsgálat alapján
}

\author{
POÓR JÓZSEF ${ }^{1}$ - JUHÁSZ TÍMEA² - HÁMORI TAMÁS³ - \\ KARÁCSONY PÉTER ${ }^{4}$ - MACHOVA RENATA ${ }^{5}$ - CSAPÓ ILDIKÓ 6
}

\begin{abstract}
ABSZTRAKT
A humánerőforrás iránti kereslet igen erôsen megváltozott az elmúlt évtizedben és átrendezôdött a munkaerőpiac keresleti és kínálati oldala egyaránt. A 2000-es évek első évtizedére a munkaerő túlkínálat volt jellemző globálisan, ezzel szemben napjainkat a munkaerőhiány jellemzi. A közép-kelet-európai országokban a 90-es években végbement kedvezôtlen gazdasági és társadalmi változások hatást gyakorolnak a jelenlegi munkaerőpiac változásaira és meghatározó szerepet játszanak a munkaerőhiány kialakulásában. A rendszerváltozás után ezen országokban kialakult magas munkanélküliség arra késztette a tehetségesebb munkavállalókat, hogy a könnyebb boldogulás reményében a nyugat-európai országok irányába mozduljanak el (Bilsen Konings 1998, Jeong et al. 2008). Napjaink egyik kulcskérdése ezen országokban a drasztikusan megnövekedett munkaerőhiány, amely kialakulását különböző tényezők befolyásolták, többek között a rendszerváltozás utáni elvándorlás, a kedvezôtlen demográfiai tényezők, a gazdasági válság és az Európai Unión belüli bérkülönbségek (Brixiova et al. 2009). Az OECD adatai alapján elmondható, hogy közel 7 millió munkavállaló hagyta el a Visegrádi országok munkaerốpiacát. A megfelelő humán tőke felkutatása, megszerzése és megtartása számos kihívás elé állítja a vállalatokat, amely hatást gyakorol a vállalatok versenyképességére és termelékenységére egyaránt. Jelen tanulmány a munkaerőhiány kialakulásának okaival és a munkaerō-megtartás lehetőségeinek vizsgálatával foglalkozik mind vállalati, mind kormányzati szinten. A kutatás folyamán közép-magyarországi régióban múködő vállalatok és közszféra szervezetei kerültek megkérdezésre. A vizsgálatok eredményei rámutatnak, hogy egyeztetés és központi szervezeti intézkedések is szükségesek a szakemberhiány megoldása érdekében mind a vállalkozások, mind a kormányzat részéról egyaránt.
\end{abstract}

KULCSSZAVAK: HR, munkaerőhiány, kormányzati intézkedések, hiányszakmák, fluktuáció

\footnotetext{
${ }^{1}$ Egyetemi tanár, Selye János Egyetem és Szent István Egyetem.

${ }^{2}$ SAP Tanácsadó.

${ }^{3}$ MSc hallgató, Szent István Egyetem.

${ }^{4}$ Egyetemi docens, Széchenyi István Egyetem.

${ }^{5}$ Egyetemi adjunktus, Selye János Egyetem (Komárom, Szlovákia).

${ }^{6}$ PhD hallgató, Szent István Egyetem.
} 
www. metszetek.unideb.hu

\section{TEMATIKUS TANULMÁNYOK - A munkaerőpiac gazdasági-társadalmi kérdései}

\section{ABSTRACT}

\section{Some questions about labour shortages in Central Hungary - based on empirical research}

Demand for human resources has changed very strongly over the past decade and the demand and supply sides of the labour market have shifted. While there was a global over-supply of labour by the first decade of the new millennium, the job market today is characterized by labour shortages. In Central and Eastern European countries, unfavourable economic and social circumstances in the 1990s have had an impact on the current labour market changes and play a decisive role in labour shortages. After the fall of communism, the resulting high unemployment in these countries led to more talented workers moving towards Western European countries in the hope of a better quality of life (Bilsen - Konings 1998, Jeong et al. 2008). One of today's key issues in former socialist countries now Member States of the European Union is the dramatically increased number of labour shortages, which have been influenced by various factors, including post-transition migration, unfavourable demographic factors, the economic crisis beginning in 2008, and wage differences within the European Union (Brixiova et al. 2009). According to OECD data, nearly 7 million people have left the labour markets in the Visegrád countries. The present study focuses on the causes of labour shortages and the analysis of labour retention opportunities at both the corporate and government levels. The results of our analysis show that reconciliation and central governmental measures are also needed to address the shortage of professionals, both from corporate and the government sides.

KEYWORDS: HR, labour shortage, governmental actions, missing job, turnover

\section{Szakirodalmi feldolgozás}

A humánerőforrás menedzsment fogalma nehezen definiálható. Tudományos szinten a HR menedzsment területeivel és azok vizsgálatával az 1900-as évek elején kezdtek foglalkozni a közgazdászok, amely az elmúlt 100 évben nagyon sok változáson ment keresztül. A közép- és kelet-európai régió országaiban az országok politikai rendszere erősen meghatározta az emberi erőforrás menedzsment területeit a múlt század második felében. Jellemzően állami irányítás alatt állt, a tradicionális „taylori vonal” volt az irányadó, a személyzeti kérdések a párt és állami vezetés felügyelete alá tartoztak. Ennek okán a régió területén a HR menedzsment eltérő módon fejlődött (Kornai 2008, Karoliny 2017).

Napjainkra a HR menedzsment komoly fejlődésen ment át, amely egy komplex, egész szervezeten átívelő tervezéssel, képzéssel és jogi háttérrel működő szakma, melynek célja a szervezet hosszú távú fennmaradása és fejlődése (Torrington et al. 2014).

A humánerőforrás menedzsment az egész szervezetet átöleli, funkciói minden területre kihatnak, egyik legfontosabb feladata a megfelelő humánerőforrás biztosítása a vállalat számára (Ulrich 2015). A modern humánerőforrás gazdálkodás fontos 


\section{TEMATIKUS TANULMÁNYOK - A munkaerőpiac gazdasági-társadalmi kérdései}

feladata a dolgozók elégedettségének biztosítása, amely által a megfelelő teljesítmény és az egyéni és szervezeti célok összhangba kerülnek egymással (Dajnoki Fenyves 2014).

A fluktuáció mértéke iparáganként és földrajzi területenként is nagyon eltérő mértéket mutat. A fluktuáció nagyságára a vállalkozásnál lévő nyitott pozíciók és a munkanélküliségi ráta is hatással van. Mathis és Meglich (2014) megállapítása szerint, amikor csökken a munkanélküliségi ráta, vele fordítottan arányosan nő a fluktuáció. A legmagasabb fluktuáció a kiskereskedelemben, a speciális tudást igénylő területeken (pl. mérnök), az építőiparban és a call centerekben figyelhető meg, amely egybeesik a hiányszakmák területeivel. Régiós eltérések is kimutathatók, magasabb fluktuáció figyelhető meg azokon a területeken, ahol alacsonyabb a munkanélküliség. Magyarországon a munkaerőhiány az elmúlt évek tendenciájához hasonlóan tovább növekedett. Szélesedett azon munkakör-kategóriák száma, ahol egyre hosszabb időt kíván a megfelelő munkaerő megtalálása és az üres, betöltetlen pozíció betöltése (Sebők 2017). A helyzet kialakulásában számottevő szerepet játszik a külföldi kivándorlás is. Egyes források (BBJ 2018) szerint ez az érték napjainkra elérte hazánkban a több mint 340 ezres értéket.

A felmérési eredmények rámutatnak arra, hogy a munkahelyi fluktuáció többféle okra vezethető vissza, ilyen tényező a munkahelyi elégedetlenség, az alacsony lojalitás mind a munkáltató, mind a munkavállaló irányába, a munka-magánélet egyensúly konfliktusa és természetesen a bérezés (Csedő et al. 2016).

A megfelelő minőségű humánerőforrás vagy bizonyos esetekben a munkavállalók elköteleződése nem megfelelő. Egy vállalkozás életében veszélyforrásként jelenik meg a magas fluktuáció. A munkaerő mozgását befolyásolja a szervezet adottsága, a vállalkozás piaci pozíciója, a regionális munkaerőpiaci jellemzők, az egyéni indítékok, a munkaerőmozgás szabadsága (Koncz 2004). A fluktuáció különböző mértékben jelenik meg a szervezetek életében, amelyekre eltérő magyarázatok lehetnek, és amely minden szervezet életében problémaként és költségként jelenik meg, ennek ellenére bizonyos helyzetekben pozitívan is befolyásolja a vállalat működését (Boudreau 2010).

A fluktuáció ellen nehéz bármit is tenni, hiszen egyrészről természetes folyamat, másrészről rengeteg külső ok játszik közre a kialakulásában. A fő kérdés az, hogy meg lehet-e előre jósolni, hogy ki fog kilépni a vállalkozástól. Vannak esetek, amikor a kilépés egy azonnali, érzelmeken alapuló döntés, de sok esetben ez egy hosszú folyamat, melyet számos esemény előz meg és vezet el a végső döntéshez (Saridakis Cary 2016). A kutatók különböző viselkedési modelleket dolgoztak ki, de mostanáig még nem sikerült olyat kialakítani, ami tökéletesen működött volna annak köszönhetően, hogy az emberi viselkedés és döntési mechanizmus rendkívül összetett folyamat (Saridakis - Cary 2016). 


\section{TEMATIKUS TANULMÁNYOK - A munkaerőpiac gazdasági-társadalmi kérdései}

A. Gomez - Mejia (1995) szerint a munkaerőpótlás költségeit a következő tényezők befolyásolják:

- A toborzási költségek, amelyek tartalmazzák a hirdetési vagy professzionális toborzással foglalkozó cég megbízásához kapcsolódó költségeket, esetleg különböző állásbörzéken vagy egyetemi karriernapokon való részvételt. Minél komplexebb szakértelmet igénylő munkakört szeretne betölteni a vállalkozás, annál magasabb költségekkel kell számolni.

- A kiválasztási költségek, amelyek tartalmazzák az interjúztatás, a jelentkezéssel járó tesztek, az utazási költségek és az interjúkészítő kieső munkájának a költségeit. Mivel nagyon sok munkáltató kulcskérdésnek tartja a kiválasztást, ezért több munkatársat is bevon a döntésbe, így az ő kieső munkaidejükkel is számolni kell.

- A betanítás költségei. Legyen bármennyire is tapasztalt az új munkatárs, meg kell ismernie a céget, be kell illeszkednie a többi munkatárs közé és meg kell tanulnia a cég termékeit, tehát elkerülhetetlen a képzés. A képzések díja mellett számolni kell azzal is, hogy ameddig oktatják a kollégát, addig sem termel.

Allen (2008) tanulmányában az önkéntes kilépés költségeit 4 fő kategóriába sorolja, amelyet az 1 . számú táblázat mutat be. Ezek a költségek komoly terhet jelentenek a vállalat számára.

1. táblázat. Önkéntes kilépés költségeinek részletezése

\begin{tabular}{|c|c|}
\hline \multirow[t]{4}{*}{ Pénzügyi költségek } & HR személyzet ideje (kilépő interjúk, bérszámfejtés, cafeteria) \\
\hline & Vezető ideje (kísérlet a megtartásra, kilépő interjú) \\
\hline & Felgyülemlett szabadság kiadása \\
\hline & Ideiglenes megoldás (esetleges pótlás, túlóra fizetése) \\
\hline \multirow[t]{5}{*}{ Helyettesítési költségek } & Új munkaerő költsége \\
\hline & $\begin{array}{l}\text { Járulékos költségek (bónusz, fizetés feletti egyéb juttatások, } \\
\text { lakhelyváltoztatás költsége) }\end{array}$ \\
\hline & A felettes vezető és a részleg alkalmazottainak ideje \\
\hline & Orientációs program ideje és anyagának összeállítása \\
\hline & HR személyzet költsége (bérszámfejtés, cafeteria igénye) \\
\hline \multirow[t]{5}{*}{ Tréningköltségek } & Kötelező tréning (gyakorlati idő, eszközök, felszerelés biztosítása) \\
\hline & On the job tréningek (felügyelő és a munkavállaló ideje) \\
\hline & Mentorálás (mentor ideje) \\
\hline & Beilleszkedés (kollégák ideje) \\
\hline & Hatékonyság csökkenése, amíg az új munkaerő be nem tanul \\
\hline
\end{tabular}


www. metszetek.unideb.hu

\section{TEMATIKUS TANULMÁNYOK - A munkaerőpiac gazdasági-társadalmi kérdései}

\begin{tabular}{|l|l|}
\hline Egyéb költségek & $\begin{array}{l}\text { Késés a termelésben vagy az ügyfél kiszolgálásában, a szolgálta- } \\
\text { tás minősége csökken }\end{array}$ \\
\cline { 2 - 2 } & Elveszett ügyfelek \\
\hline & $\begin{array}{l}\text { Ügyfelek nem kapják meg azt, amit akkor kaptak volna, ha a } \\
\text { dolgozó marad }\end{array}$ \\
\hline & $\begin{array}{l}\text { Szorosabb verseny, dolgozó konkurens céghez megy, vagy saját } \\
\text { vállalkozást indít }\end{array}$ \\
\hline $\begin{array}{l}\text { A távozás miatt a munkakedv csökkenhet, másokat is távozásra } \\
\text { késztethet }\end{array}$ \\
\hline Csapatmunka megbomlása \\
\cline { 2 - 2 } & Munkaerő sokszínúség elvesztése \\
\hline
\end{tabular}

Forrás: Dajnoki - Fenyves (2014: 7)

A korábban idézett szerző szerint a fluktuáció nem olcsó dolog. A beosztott munkakörök esetében egy munkavállaló kilépése és pótlása az éves bérének a felével egyenlő. Magasabb kategóriájú és komplexebb pozícióknál meghaladhatja az éves bér egy- és kétszeresét is (Boudreau 2010). Egy legújabb hazai kutatás szerint egy új dolgozó pótlása hazánkban meghaladhatja az egymillió forintot (Blooment - BDO 2017).

A vállalkozások az ideális fluktuációs mérték megállapításához szükséges adatokat a saját célpiacaikról és belső dolgozói adatállományukból szerzik be, amely hozzájárul az ideális fluktuációs mérték meghatározásához. A fluktuáció ideális nagyságát minden vállalkozásnak saját magának kell megállapítania. Módszereit tekintve érdemes kategóriákat létrehozni a dolgozók teljesítménye, a pozíció, az életkor, a nem és a szolgálati idő alapján (Ambrus - Lengyel 2006).

Redman és Wilkinson (2006) megállapítják, hogy a létszámcsökkentés eszközként is megjelenhet a szervezetek működésében, hiszen ezzel növelhetővé válik a szervezet termelékenysége és hatékonysága. Ennek ellenére sok vállalkozás nem alkalmazza eszközként a létszámcsökkentést, mert a kutatások eredményei arra mutatnak rá, hogy a létszámcsökkentés negatív eseményként marad meg a vállalkozás életében (Burke 1997).

Blandy - Richardson (1992) szerint hiányszakmának lehet nevezni, ha a szabad munkaerő adott bérszínvonal mellett nem képes betölteni a szabad álláshelyeket, közelebbről vizsgálva azonban sokkal összetettebb a kép. Egy másik megfogalmazás szerint akkor beszélünk szakemberhiányról, amikor a munkaerőpiaci egyensúly felborul, mert a keresett munkaerő létszáma meghaladja azt a kínálatot, amennyien adott bérek mellett hajlandóak és képesek is dolgozni, adott munkakörülmények között, adott helyen és időben, megfelelő tapasztalattal és végzettséggel (Barnow et al. 1998). Ez a fajta hiány bármely iparágban jelentkezhet, a szakképzett, alacso- 


\section{TEMATIKUS TANULMÁNYOK - A munkaerőpiac gazdasági-társadalmi kérdései}

nyan képzett, félig képzett és képzetlen munkaköröket is érintheti. Csedő és társai által végzett (2016) felmérés szerint a betöltetlen pozíciók aránya igen magas a következő területeken: IT specialista, mérnök, minőségbiztosítási mérnök, tanácsadó, gépészmérnök és pincér. A szakemberhiány az alacsony bérekre, a képzettség hiányára és a versenytársaknál lévő kedvezőbb feltételekre vezethető vissza. Ezeket az eredményeket a 2017-ben és 2018-ban a Szent István Egyetem Menedzsment és HR Kutató Központ által elvégzett újabb kutatások eredményei is alátámasztják (Poór et al. 2017, 2018).

Az alacsony munkanélküliség és a vállalatok változó képzettségi igénye miatt is kialakulhat munkaerőhiány, emellett további okok is kiválthatják, mint például a változó technológiai környezet, például robotizáció, informatikai fejlődés; a gyors gazdasági növekedés miatt fellépő, növekvő termelési igény; a munkaerő-elvándorlás, gazdasági, vallási vagy politikai okok miatt, illetve az öregedő társadalom miatt sokan lesznek nyugdíjasok, miközben kevesebb az új munkavállaló.

Richardson (2007) véleménye szerint a munkavállalóknak sokkal többrétű tudásra van szüksége, mint az adott szakmához szükséges professzionális tudás, a magasabb pozícióknál a szakmai tudás mellett a személyiségbeli elvárások listája szinte végtelen.

A szakemberhiány egy nemkívánatos gazdasági állapot, amely megoldására a szervezetek eltérő intézkedéseket alkalmaznak, ilyen például a nem megfelelő szaktudással rendelkező dolgozó felvétele magasabb bérszínvonalon vagy alacsonyabb termelékenységi szinten; a megfelelő szakképzettséggel rendelkező dolgozókat különböző ösztönzőkkel túlórára bírják; megpróbálják a fizikai tőkét humán tőkével helyettesíteni; ösztönzik az országon belüli vagy nemzetközi lakóhelyváltást, vagy csökkentik a termelési szintet (Borghans 1997).

Az intézkedések minden esetben plusz költséget jelentenek a szervezet múködésében. Igaz, ezen alternatívák alkalmassá válnak a szakemberhiány megszüntetésére azokban az esetekben, amikor a vállalkozásoknak nehéz vagy nagyon költséges új szakembert felvenni, illetve a hiányszakmák területén a munkaerőpiaci verseny megerősödik, amely a bérköltségek emelkedéséhez vezet. Minél alacsonyabb költségeken lehet ezen alternatívákat kivitelezni, annál inkább csökkenthető a szakemberhiány által okozott kár. Továbbra is szükséges hangsúlyozni, hogy ezek a megoldások nem szüntetik meg a szakemberhiányt, csupán a gazdaságra tett negatív hatások csökkennek. Az eltérő megoldások pozitív hatásai közé sorolhatók az alacsonyabb szintű szakemberhiány által generált költségek, negatív hatása viszont a többletköltségek vagy termelékenység csökkenése a „nem szakemberhiányos” állapothoz képest (Borghans 1997).

A munkaerőhiány kérdését a vállalkozások eltérő módon kezelik, de ez önmagában nem elegendő, kormányzati intézkedésekre is szükség van. Farrel (2013) kutatásai alapján a kormányok három fontos intézkedést tehetnek képzési oldalon a szakemberhiány elkerülése érdekében: információgyűjtés és -terjesztés, szektoro- 


\section{TEMATIKUS TANULMÁNYOK - A munkaerőpiac gazdasági-társadalmi kérdései}

kon átívelő együttmúködések segítése, és egy oktatásból a munkába kerülést segítő rendszer létrehozása. A fiataloknak kevesebb, mint a fele rendelkezik elegendő információval a munkaerőpiaci trendeket illetően. Mindez elkerülhető a kormányok által nyújtott megfelelő tájékoztatással (pl. a várható diplomások végzettsége az elkövetkező években), amely segíti a tervezést, szakmaválasztást és elhelyezkedést. Ezen információk a munkavállalókat, az oktatási intézményeket és a vállalkozásokat is nagyban segíthetik hosszú távú stratégiájuk kialakításában. Ezért olyan megoldásokat kell létrehozni a jövőre nézve, amelyek kidolgozásában együttmüködnek az oktatási intézmények, a kormány és a vállalkozások egyaránt, annak érdekében, hogy közösen tervezzenek és oldják meg az ágazatokon belüli szakemberhiányt. Mivel együttmúködésről van szó, a költségek is megoszlanak, ami tovább növelheti a részvételi hajlandóságot. A kormány nagy szerepet tud betölteni az ilyenfajta együttműködések megszervezésében és elindításában. Keszthelyi (2016) rávilágít arra, hogy újragondolt adópolitika és megfelelően kezelt szociális juttatások segíteni tudják a Magyarországon kialakult szakemberhiány menedzselését. A vállalkozások véleménye alapján elmondható, hogy az alternatív munkamódszerek alkalmazásának lehetőségét magasabb mértékben szükséges támogatni az állam részéről, amely megoldást tud nyújtani hosszú távon a munkaerőhiány-szakemberhiány kérdéseire.

Csedő és szerzőtársai (2016) által végzett kutatási eredmények szerint a megkérdezett szervezetek több mint fele a leghatékonyabb kormányzati eszköznek tartja a képzési programok támogatását és szervezését (duális és speciális szakmai); az átfogóbb és részletesebb jövedelemtámogatási rendszer kialakítását; a vállalkozások támogatását gyermeknapközik és óvodák létrehozására vagy speciális munkaerőpiaci szolgáltatások bevezetését.

A korábban már idézett Keszthelyi (2016) véleménye szerint, a szakemberhiány további növekedését csökkenteni lehetne, ha sikerül megállítani a lakosság külföldi kivándorlását. Megállapítja, hogy nem a kivándorlás a legnagyobb gond, hanem annak a jelenségnek a hiánya, amely megfigyelhető a gazdagabb országokban is: pár év külföldi munka után hazaköltöznek a munkavállalók. Nagyon fontos lenne, ha a külföldön dolgozók számára ismét vonzó munkakörülményeket lehetne biztosítani hazai viszonylatban.

A Randstad (2016) által készített felmérés szerint a hazai munkavállalók 82\%-a problémásnak tartja a bérek és a béren kívüli juttatások alacsony színvonalát, és Magyarországon a munkaképes korú lakosság csupán 65\%-a dolgozik, amely alacsonyabb az európai átlagnál.

A munkaerőhiány kezelésére megoldást adhat a robotizáció, amely már jelen van. Ford (2016) véleménye, hogy napjainkban a munkaerőhiányt jelentő területek az új típusú robotizáció hatására hamarosan megszűnnek. Smith (2016) tanulmányában rámutat, hogy 50 év múlva vélhetően a robotok, komputerek és automata rendszerek több munkát fognak végezni, mint élő emberek. Az önjáró autóktól kezdve, a 


\section{TEMATIKUS TANULMÁNYOK - A munkaerőpiac gazdasági-társadalmi kérdései}

félautomata robotokon át, az intelligens algoritmusokig, már napjainkban is nagyon sok munkát végeznek a gépek az emberek helyett. Egy kutatás alapján (Hess - Ludwig 2017) elmondható, hogy az USA-ban lévő állások 47\%-a van „veszélyben” a robotizáció miatt. Anandan (2015) szerint nem az a kérdés, hogy lesz-e robotizáció, vagy szükséges-e, hanem az, hogy mikor kezdik el a vállalkozások alkalmazni a különböző munkaterületeken. A jelenlegi szakemberhiányos állapot nagyban felgyorsítja az eseményeket. Ez az irány azonban hatással lesz a képzésre és a kormányzati programokra is, hiszen a robotok tervezését, működtetését, programozását egyelőre emberek oldják meg, mindaddig, amíg ezek a robotok nem érik el a fejlődésük azon szintjét, amikor az önfejlesztővé és önjavítóvá válik.

Smith (2014) véleménye szerint valószínűtlen, hogy a robotizált munkakörökben teljesen átvegyék a robotok a munkát az emberektől. Az előző okfejtések lezárásaként érdemes idézni a jövőkutató Hararit, aki szerint „egy vagy két évtizeden belül kétmilliárd ember válik gazdaságilag feleslegessé”, míg „mások arra hívják fel a figyelmet, hogy a jelzett változás nagyon sok új munkahelyet fog teremteni" (Harari 2018: 29).

\section{A kutatás módszere ${ }^{7}$}

A kérdőíves vizsgálat során 174 szervezet válaszát dolgoztuk fel. A megkérdezett szervezetek jellemzően a közép-magyarországi régióban helyezkedtek el, amely Magyarország egyik legfejlettebb régiójának számít.

Az alkalmazott kérdőív három fő területre bontható, az első része jellemzően a minta specifikálására épült, azaz a szervezetek elhelyezkedésére, ágazati besorolására, éves árbevételre és létszámadatokra kérdezett rá. A második része elemezte a fluktuáció mértékét és a legnehezebben betölthető pozíciók jellemzőit, valamint a munkaerőhiány leküzdéséhez köthető vállalati intézkedések kérdésköreit. A harmadik része vizsgálta a munkaerőhiány kezelésére és megoldására létrejövő állami és szervezeti intézkedések értékelését.

A kérdőívre adott válaszokat statisztikai elemzési módszerekkel az IBM SPSS Statistics program segítségével dolgoztuk fel. Az elemzés során leíró és következtető statisztikákat alkalmaztunk.

Elemzésünkben az alábbi hipotézist vizsgáltuk:

- A kutatásban részt vevő cégek úgy látják, hogy mind kormányzati, mind szervezeti intézkedések feltétlenül szükségesek a szakemberhiány megoldásában.

${ }^{7}$ A szerzők köszönetet mondanak Csedő Csabának, Frajna Piller Annamáriának és Kolbe Tamásnak az empirikus vizsgálatban való közreműködésükért. 
www. metszetek.unideb.hu

\section{TEMATIKUS TANULMÁNYOK - A munkaerőpiac gazdasági-társadalmi kérdései}

\section{Kutatási eredmények}

A megkérdezett szervezetek a közép-magyarországi régióban találhatóak, 46,6\%-a hazai magántulajdonú vállalkozás, 7,5\%-uk hazai külföldi tulajdonú vállalkozás, 35,1\%-uk külföldi tulajdonossal rendelkező vállalkozás és 10,9\%-uk vegyes tulajdonosi formával rendelkező szervezet. A legnagyobb arányban a szolgáltató (29,9\%) és ipari (10,9\%) szektor képviselői töltötték ki a kérdőívet.

A megkérdezett vállalatok 21,8\%-a több mint 1000 fót alkalmazott. A mintában minden tizedik cég 500-1000 fő közötti munkavállalói létszámmal rendelkezett, minden nyolcadik 10-51 fő közötti, illetve 2-9 fö közötti munkavállalói létszámállományú volt.

A megkérdezett szervezetek éves árbevételét vizsgálva megállapítható, hogy a legnagyobb gyakorisággal az 1-10 Mrd Ft közötti (23,6\%) és a 100 millió és 1 Mrd Ft közötti $(20,1 \%)$ szervezetek fordultak elő.

2015-ben átlagosan a leggyakoribb fluktuációs arány 5-10\% között volt, de 7 cég esetében ez elérte a 40\% feletti nagyságot is. A kereskedelmi és szolgáltató szektorban működő vállalatok körében volt ilyen magas a fluktuáció. A felsőfokú végzettségűek esetében leginkább a 0-5\%-os arányú fluktuáció a leggyakoribb, míg a fizikai dolgozók mindössze 42,3\%-a nem vált munkahelyet. A 2. táblázat az ágazatonkénti hiányszakmákat mutatja be.

2. táblázat. Ágazatonkénti hiányszakmák a válaszok tükrében

\begin{tabular}{|l|l|}
\hline \multicolumn{1}{|c|}{ Ágazatok } & \multicolumn{1}{c|}{ Hiányszakmák } \\
\hline Ipar & $\begin{array}{l}\text { értékesítési vezető, gépkezelő, kőműves } \\
\text { mérnök (villamos, gépész, minőségi), villanyszerelő }\end{array}$ \\
\hline Kereskedelem & $\begin{array}{l}\text { általános adminisztráció, autószerelő, } \\
\text { eladó, pénztáros, IT szakember }\end{array}$ \\
\hline Informatika & $\begin{array}{l}\text { tanácsadó, értékesítő, szoftverfejlesztő, } \\
\text { programozó, rendszermérnök, SAP fejlesztő }\end{array}$ \\
\hline Logisztikai szolgáltatás & gépkocsivezető, projektvezető \\
\hline Mezőgazdaság & fizikai dolgozó \\
\hline Szolgáltatás & $\begin{array}{l}\text { ügyfélszolgálat, operátor, értékesítő, } \\
\text { könyvelő, IT tanácsadó, pincér/felszolgáló }\end{array}$ \\
\hline Közigazgatás & HR specialista, informatikus, projektmenedzser \\
\hline
\end{tabular}

Forrás: Szerzők saját szerkesztése

A válaszadók szerint leginkább 8, illetve 12 hét szükséges az adott munkakörök betöltésére, igaz, voltak olyan szélsőséges esetek, amikor a munkakör betöltésének ideje jóval hosszabb időt vett igénybe, ilyen például a felszolgáló vagy IT szakemberek. 


\section{TEMATIKUS TANULMÁNYOK - A munkaerőpiac gazdasági-társadalmi kérdései}

A szervezetekben jelentkező munkaerőhiány és a szervezeten belüli munkaerő-megtartás fontos kérdés a megkérdezett szervezeteknél, amelyekre eltérő ösztönző eszközöket alkalmaznak. A 3. számú tábla tartalmazza azokat az ösztönző eszközöket, amelyeket a megkérdezett szervezetek alkalmaznak a munkatársak hosszú távú megtartása érdekében.

3. táblázat. Alkalmazott eszközök a munkaerőhiány kezelésére és a munkatársak megtartására (\%)

\begin{tabular}{|c|c|c|c|c|c|}
\hline Eszközök & $\begin{array}{l}\text { Jelenleg is } \\
\text { alkalmaz- } \\
\text { zuk } \\
\end{array}$ & $\begin{array}{l}\text { Tervezzük } \\
\text { alkalma- } \\
\text { zását } \\
\end{array}$ & $\begin{array}{c}\text { Nem tervez- } \\
\text { zük alkal- } \\
\text { mazását } \\
\end{array}$ & $\begin{array}{c}\text { Nálunk ez } \\
\text { nem alkal- } \\
\text { mazható }\end{array}$ & \begin{tabular}{|c|} 
Kevés \\
ismeretem \\
van róla \\
\end{tabular} \\
\hline Cégautó juttatás & 41,0 & 2,6 & 35,9 & 16,7 & 3,8 \\
\hline $\begin{array}{l}\text { Extra szabadságnapok bizto- } \\
\text { sítása }\end{array}$ & 43,6 & 1,3 & 42,3 & 10,3 & 2,6 \\
\hline $\begin{array}{l}\text { Bérfelmérésben való részvétel, } \\
\text { és a tapasztalatok beépítése a } \\
\text { javadalmazási rendszerbe }\end{array}$ & 46,3 & 13,4 & 22,0 & 11,0 & 7,3 \\
\hline $\begin{array}{l}\text { Általános kompetencia érté- } \\
\text { kelési és fejlesztési program }\end{array}$ & 48,8 & 28,8 & 17,5 & 1,3 & 3,8 \\
\hline $\begin{array}{l}\text { Speciális képzési program, } \\
\text { egyéni fejlesztési terv }\end{array}$ & 50,0 & 30,0 & 16,3 & 2,5 & 1,3 \\
\hline $\begin{array}{l}\text { Karrier- és utánpótlás me- } \\
\text { nedzsment program }\end{array}$ & 50,6 & 30,4 & 15,2 & 3,8 & 0,0 \\
\hline $\begin{array}{l}\text { Béren kívüli juttatások rend- } \\
\text { szerének átalakítása }\end{array}$ & 55,6 & 17,3 & 22,2 & 3,7 & 1,2 \\
\hline Gyakornoki program & 59,3 & 16,0 & 19,8 & 3,7 & 1,2 \\
\hline $\begin{array}{l}\text { Bérezési, fizetési rendszer } \\
\text { átalakítása }\end{array}$ & 60,5 & 7,4 & 19,8 & 6,2 & 6,2 \\
\hline $\begin{array}{l}\text { Munkavállalói elégedettség és } \\
\text { elkötelezettség felmérése }\end{array}$ & 63,3 & 22,8 & 10,1 & 2,5 & 1,3 \\
\hline $\begin{array}{l}\text { Atipikus foglalkoztatási formák } \\
\text { (részmunkaidő, osztott munka- } \\
\text { kör, távmunka) }\end{array}$ & 64,2 & 11,1 & 14,8 & 8,6 & 1,2 \\
\hline $\begin{array}{l}\text { Munkavégzési körülmények } \\
\text { javítása }\end{array}$ & 67,9 & 16,7 & 11,5 & 3,8 & 0,0 \\
\hline $\begin{array}{l}\text { Rugalmas munkaidő alkalma- } \\
\text { zása }\end{array}$ & 71,3 & 11,3 & 7,5 & 8,8 & 1,3 \\
\hline $\begin{array}{l}\text { Teljesítményértékelési és pré- } \\
\text { miumrendszer }\end{array}$ & 79,0 & 11,1 & 7,4 & 2,5 & 0,0 \\
\hline
\end{tabular}

Forrás: Szerzők saját szerkesztése 


\section{TEMATIKUS TANULMÁNYOK - A munkaerőpiac gazdasági-társadalmi kérdései}

A megkérdezett szervezetek igen gyakran alkalmazzák a megszerzés és megtartás eszközeként a teljesítményértékelést és prémiumrendszerek használatát, a rugalmas munkaidőt, az atipikus foglalkoztatási formákat, avagy javítják a munkakörülményeket. Az additív juttatások, mint céges autó, béren kívüli juttatások bevezetése sok cég esetében nem éri el a tervezés fázisát sem.

Az ösztönző rendszerek és bérrendszerek versenyképesebbé tételének kérdéskörét illetően a szervezetek nemcsak magukra támaszkodhatnak, hanem állami segítségre is, mivel az állam számos intézkedést hozhat a munkaerőhiány kezelésére. Kérdés azonban, hogy ennek hatékonysága és sikeressége mennyire igazolható. A szervezeteket a felmérés folyamán megkérdeztük, hogy véleményük szerint menynyire tekinthetők eredményesnek a különböző kormányzati intézkedések és megoldások. (Ezt a vizsgálatot egy ötfokozatú Likert-skálán végeztük, amely esetében az 1-es az egyáltalán nem hatékonyságot, míg az 5-ös a teljes hatékonyságot jelentette.) Ezt mutatja a 4. táblázat.

4. táblázat. Kormányzati intézkedések hatékonysága (átlag, szórás)

\begin{tabular}{|c|c|c|}
\hline Kormányzati intézkedések & Átlag & Szórás \\
\hline $\begin{array}{l}\text { Külföldi munkavállalók betelepedésének ösztönzése, támogatása } \\
\text { a világ bármely tájáról }\end{array}$ & 2,23 & 1,321 \\
\hline $\begin{array}{l}\text { Közmunkában dolgozók nem közigazgatásban müködő szervezetek általi } \\
\text { alkalmazhatósága, „kölcsönözhetősége” }\end{array}$ & 2,38 & 1,517 \\
\hline $\begin{array}{l}\text { Külföldi munkavállalók betelepedésének ösztönzése, támogatása } \\
\text { Európából }\end{array}$ & 2,51 & 1,292 \\
\hline Nyelvtanítás külföldi munkavállalók számára & 2,56 & 1,277 \\
\hline $\begin{array}{l}\text { Külföldi munkavállalók betelepedésének ösztönzése, támogatása } \\
\text { Közép-Európából }\end{array}$ & 2,57 & 1,335 \\
\hline Áttelepedési támogatás (külön bel- és külföldi áttelepedés esetén) & 2,87 & 1,327 \\
\hline $\begin{array}{l}\text { Közlekedés fejlesztése, munkába járási hozzájárulás (pl. vállalati buszok } \\
\text { támogatása) }\end{array}$ & 3,37 & 1,26 \\
\hline Lakhatási támogatások (építés, munkásszállás, albérlet) alkalmazása & 3,58 & 1,246 \\
\hline Vállalati bölcsődék és óvodák támogatása & 3,70 & 1,433 \\
\hline Speciális munkaerőpiaci szolgáltatások bevezetése & 3,76 & 1,203 \\
\hline $\begin{array}{l}\text { Diákmunka szerepének növelése (közép- és felsőfokú hallgatók bevonása } \\
\text { a munkaerőpiacra) }\end{array}$ & 3,77 & 1,099 \\
\hline Bértámogatási rendszer kiterjesztése & 3,80 & 1,234 \\
\hline $\begin{array}{l}\text { Képzési programok ösztönzése, támogatása (duális képzés, speciális } \\
\text { szakképzési programok) }\end{array}$ & 3,84 & 1,163 \\
\hline $\begin{array}{l}\text { Atipikus munkavállalási formák támogatása (pl. távmunka, részmunkaidő, } \\
\text { osztott munkakör stb.) }\end{array}$ & 4,05 & 1,2 \\
\hline Adózási/járulékrendszer átalakítása & 4,42 & 0,9 \\
\hline
\end{tabular}

Forrás: Szerzők saját szerkesztése 


\section{TEMATIKUS TANULMÁNYOK - A munkaerőpiac gazdasági-társadalmi kérdései}

A kapott eredmények azt mutatják, hogy a szervezetek leginkább az adózási és járulékrendszer átalakításában látnak megoldási lehetőséget a problémára. Továbbá az atipikus munkavállalási formák, a képzési programok ösztönzése jelenthet hatékony lehetőséget a munkaerő-megtartás kezelésére. Ez utóbbi esetekben azonban magasak a szórás értékek, nem úgy, mint az adózási és járulékrendszer átalakítása során, amely tekintetében viszonylag egyöntetű volt a válaszadók véleménye. A vélemények alapján a szervezetek nem bíznak a külföldi munkavállalók betelepítésében, amely mintegy megoldhatná a szakemberhiányt.

A kapott eredmények vizsgálatai alapján az adott változókat faktorokba redukáltuk. Az állítások alkalmasak voltak a faktorképzésre: KMO érték: 0,648, a Bartlett-teszt: Khi-négyzet: 412,219, df: 105 szign: 0,00. Valamennyi változó kommunalitása magasabb volt, mint a hüvelykujjszabályként elfogadott 0,25-ös érték (Sajtos - Mitev 2007). A faktorok rotálása ortogonális forgatási módszerrel, azon belül is Varimax-eljárással történt. Az összes faktorsúly az igazán fontosnak ítélt 0,5-ös abszolút értéket meghaladta, így valamennyi változó hozzájárult a faktorelemzéshez. A faktorok magyarázott varianciahányada 68,4\% lett, amely elfogadhatónak tekinthető. A faktor komponenseket mutatja az 5. táblázat.

5. táblázat. Faktor komponensek

\begin{tabular}{|c|c|c|c|c|}
\hline \multirow{2}{*}{ Vizsgált tényezők } & \multicolumn{4}{|c|}{ Komponens } \\
\hline & 1 & 2 & 3 & 4 \\
\hline $\begin{array}{l}\text { Külföldi munkavállalók betelepedésének ösztönzése, } \\
\text { támogatása Európából }\end{array}$ & ,943 & & & \\
\hline $\begin{array}{l}\text { Külföldi munkavállalók betelepedésének ösztönzése, } \\
\text { támogatása Közép-Európából }\end{array}$ & ,932 & & & \\
\hline $\begin{array}{l}\text { Külföldi munkavállalók betelepedésének ösztönzése, } \\
\text { támogatása a világ bármely tájáról }\end{array}$ & 875 & & & \\
\hline Nyelvtanítás külföldi munkavállalók számára &, 571 & & & \\
\hline Vállalati bölcsődék és óvodák támogatása & & ,844 & & \\
\hline $\begin{array}{l}\text { Közlekedés fejlesztése, munkába járási hozzájárulás } \\
\text { (pl. vállalati buszok támogatása) }\end{array}$ & & ,792 & & \\
\hline $\begin{array}{l}\text { Képzési programok ösztönzése, támogatása (duális képzés, } \\
\text { speciális szakképzési programok) }\end{array}$ & & ,644 & & \\
\hline $\begin{array}{l}\text { Atipikus munkavállalási formák támogatása (pl. távmunka, } \\
\text { részmunkaidő, osztott munkakör stb.) }\end{array}$ & & ,614 & & \\
\hline $\begin{array}{l}\text { Lakhatási támogatások (építés, munkásszállás, albérlet) } \\
\text { alkalmazása }\end{array}$ & &, 550 & & \\
\hline Speciális munkaerőpiaci szolgáltatások bevezetése & & & 847 & \\
\hline Bértámogatási rendszer kiterjesztése & & & 810 & \\
\hline Adózási/járulékrendszer átalakítása & & & ,723 & \\
\hline
\end{tabular}


www. metszetek.unideb.hu

\section{TEMATIKUS TANULMÁNYOK - A munkaerőpiac gazdasági-társadalmi kérdései}

\begin{tabular}{|c|c|}
\hline $\begin{array}{l}\text { Közmunkában dolgozók nem közigazgatásban múködő } \\
\text { szervezetek általi alkalmazhatósága, „kölcsönözhetősége” }\end{array}$ & 716, \\
\hline $\begin{array}{l}\text { Áttelepedési támogatás (külön bel- és külföldi áttelepedés } \\
\text { esetén) }\end{array}$ & 684, \\
\hline $\begin{array}{l}\text { Diákmunka szerepének növelése (közép- és felsőfokú } \\
\text { hallgatók bevonása a munkaerőpiacra) }\end{array}$ &,- 562 \\
\hline
\end{tabular}

Forrás: Szerzők saját szerkesztése

A faktorsúlyok alapján a faktorok a következőképpen azonosíthatóak:

1. faktor: Külföldi munkavállalók betelepítési lehetősége.

2. faktor: A munkavállalást támogató szociális szolgáltatások növelése.

3. faktor: Bér-, adó- és járulékirányú intézkedések.

4. faktor: A köz- és diákmunkával kapcsolatos megoldások.

Az ANOVA elemzések azt mutatják, hogy a tulajdonosi formák alapján nincs szignifikáns különbség az adott faktorokat vizsgálva. Hasonló eredményeket kaptunk, amikor a létszám alapján vizsgáltuk a szignifikáns különbséget a faktorok tekintetében.

A kérdőív eltérő állításokat tartalmazott a munkaerőhiány leküzdésére vonatkozóan, és azt vizsgáltuk, hogy a szervezetek milyen mértékben értenek egyet az adott állításokkal. (Ötfokozatú Likert-skálán az egyes az egyáltalán nem, míg az ötös a teljes egyetértést jelentette.) A válaszok átlaga és szórása a 6. táblázatban látható.

6. táblázat. A munkaerőhiány leküzdése (átlag, szórás)

\begin{tabular}{|l|c|c|}
\hline \multicolumn{1}{|c|}{ Állítás } & Átlag & Szórás \\
\hline Akik tőlünk elmennek, többnyire külföldön vállalnak munkát & 2,64 & 1,272 \\
\hline $\begin{array}{l}\text { A szakképzett, nyelveket beszélő szakemberek kivándorlása komoly } \\
\text { gondokat okoz vállalatunknál }\end{array}$ & 2,87 & 1,398 \\
\hline $\begin{array}{l}\text { Szervezetünk vezetői szorgalmazzák az innovatív HR megoldások alkal- } \\
\text { mazását }\end{array}$ & 2,96 & 1,246 \\
\hline $\begin{array}{l}\text { Egyre nehezebb a környező országokból betölteni az üres munkakörö- } \\
\text { ket, mert a munkavállalók más országokat szívesebben választanak }\end{array}$ & 3,29 & 1,263 \\
\hline $\begin{array}{l}\text { Ma a 18-35 éves korosztály vonzása és megtartása jelenti a vállalatunk } \\
\text { / szervezetünk számára a legkihívóbb feladatot }\end{array}$ & 3,91 & 1,088 \\
\hline $\begin{array}{l}\text { Növeli a tehetséges munkavállalók lojalitását, ha innovatív ötleteik meg- } \\
\text { valósításához a szervezet kereteket biztosít }\end{array}$ & 4,18 & 0,952 \\
\hline $\begin{array}{l}\text { Egy vállalat, szervezet vonzerejét növeli az etikus üzleti magatartás és a } \\
\text { fenntartható müködés }\end{array}$ & 4,29 & 0,824 \\
\hline $\begin{array}{l}\text { A sikeres toborzás komplex megközelítést kíván, amely a bevonzani } \\
\text { kívánt célcsoport motivációinak alapos ismeretét igényli }\end{array}$ & 4,45 & 0,832 \\
\hline
\end{tabular}

Forrás: Szerzők saját szerkesztése 


\section{TEMATIKUS TANULMÁNYOK - A munkaerőpiac gazdasági-társadalmi kérdései}

Megállapítható, hogy az X és az Y korosztály megtartása egy adott munkahelyen nehézséget jelent a cégek számára. A kapott válaszok értékelése rámutat, hogy a kivándorlás nem okoz akkora dilemmát a válaszolóknak, igaz többé-kevésbé problémát jelent a környező országokból idevonzani a megüresedett helyekre a munkaerőt. A munkaerő megszerzése és megtartása abban az esetben lehetséges, ha a szervezetek egy etikus, komplex, innovatív magatartást és vállalati értékrendet biztosítanak a munkavállalóik számára

\section{Konklúzió}

A tanulmány egy 2018-ban készült kutatás néhány eredményét mutatta be. A vizsgálatból megállapítható, hogy mind a szervezeti, mind a kormányzati lépések szükségesek ahhoz, hogy a jelenleg fennálló szakemberhiányt a szervezetek meg tudják oldani. Ezek a lépések nem feltétlenül a külföldi munkavállalókkal történő szakemberfeltöltést jelentik, hanem a hazai dolgozók itthon maradását segítő intézkedésekkel - ilyen intézkedések közé tartozik a képzési és ösztönzési rendszerek alkalmazása, magasabb munkabérek és a bér-, az adózási és járulékrendszer munkaerőbarát mivoltát erősítő intézkedések - oldható meg.

A kormányzati oldalon szükséges lépésekkel párhuzamosan a szervezetek részéről is fontos számos innovatív, megelőző és átfogó intézkedést alkalmazni a munkaerő-megtartás érdekében. A szervezeti és kormányzati megoldások összehangoltan, egymást kölcsönösen kiegészítve, illetve egymással együttműködve pozitív hatást gyakorolhatnak a munkaerőhiány kezelésére. Magyarország hosszú távú versenyképességének a megőrzése érdekében stratégiai szinten kell kezelni a tehetségek gondozását, annak érdekében, hogy a legmotiváltabb és legjobban képzett szakemberek tudják betölteni a munkaköröket.

A tanulmányunk korlátja, hogy egy időszak (2016. május-július) alatt gyűjtött adatok alapján próbáltunk véleményt formálni. Jövőbeli tervünk, hogy hét (Ausztria, Cseh Köztársaság, Lengyelország, Magyarország, Románia, Szerbia, Szlovákia) közép-kelet-európai országban végzett empirikus kutatás alapján próbálunk felvázolni a vizsgált témával összefüggő lehetséges trendeket és tendenciákat, amelynek eredményeit a későbbiekben fogjuk bemutatni.

\section{Irodalom}

Allen, G. D. (2008): Retaining Talent. SHRM Foundation. United States of America. http://www.shrm.org/about/foundation/research/documents/retaining\% 20talent\%20final.pdf. (Letöltve: 2017.10.07.)

Ambrus, T. - Lengyel, L. (2006): Humán controlling számítások. CompLex Kiadó, Budapest. 


\section{TEMATIKUS TANULMÁNYOK - A munkaerőpiac gazdasági-társadalmi kérdései}

Anandan, T. M. (2015): Closing the Skills Gap in Automation: A Call for Action. Robotic Industries Association. www.robotics.org (Letöltve: 2015.04.30.)

Barnow, B. - Trutko, J. - Lerman, R. (1998): Skill Mismatches and Worker Shortages: The Problem and Appropriate Responses. Urban Institute Policy Memorandum. (Prepared for theWashington (DC), Department of Labor, Washington (DC).

BBJ. (2018): Hungarians working abroad above EU average. Budapest Business Journal (BBJ). https://bbj.hu/analysis/hungarians-working-abroad-above-euaverage-_149883 (Letöltve: 2019.01.11.)

Bilsen, V. - Konings, J. (1998): Job Creation, Job Destruction, and Growth of Newly Established, Privatized, and State-Owned Enterprises in Transition Economies: Survey Evidence from Bulgaria, Hungary and Romania. Journal of Comparative Economics, 26 (3), 429-445.

Blandy, R. - Richardson, S. (eds.) (1982): How Labour Markets Work. Longman Cheshire, Melbourne.

Blooment - BDO (2017): Jelentős munkaerőgondok Kelet-Közép-Európában. Adóonline. https://ado.hu/munkaugyek/bdo-jelentos-munkaerogondok-kelet-kozep-europaban/ (Letöltve: 2019.01.11.)

Borghans, L. - Grip, A. - Smoorenburg, M. (1997): The definition of skills shortages. Centre for Education and the Labour Market. Maastricht University, Maastricht.

Boudreau, J. W. (2010): Retooling HR. Harvard Business Press, Boston.

Brixiova, Z. - Li, W. - Yousef, T. (2009): Skill shortages and labor market outcomes in Central Europe. Economic Systems, 33 (1), 45-59.

Burke, W. W. (1997): The new agenda for organization development. Organizational Dynamics, 26 (1), 6-20.

Csedő, Cs. - Frajna-Piller, A. - Horváth, A. - Kolbe, T. - Kovács, T. - Poór, J. (2016): Szakemberhiány és munkaerő-megtartás kulcsmunkakörökben. Szent István Egyetem Menedzsment és HR Kutató Központ, Budapest.

Dajnoki, K. - Fenyves, V. (2014): Fluktuációs sajátosságok feltárása egy multinacionális szervezet példáján keresztül. Humán Innovációs Szemle, 5 (1-2), 6-17.

Daniels, K. (2010): Employee Engagement. CIPD, London.

Farrel, D. (2013): Education to Employment: What Can Government Do About the Skills Gap? Education, Law\&Goverment. https://www.linkedin.com/pulse/ 20130718183920-258795020-education-to-employment-what-can-government-do-about-the-skills-gap/ (Letöltve: 2019.01.11.)

Ford, M. (2016): Robotok kora. HVG könyvek, Budapest.

Gomez-Mejia, L. R. - Balkin, D. B. - Cardy, R. L. (1995): Managing human resources. Prentice Hall, Englewood Cliffs (NJ). 


\section{TEMATIKUS TANULMÁNYOK - A munkaerőpiac gazdasági-társadalmi kérdései}

Harari, N. Y. (2018): 21 Lessons for the 21st Century. Jonathan Cape, London.

Hess, D.E. - Ludwig, K. (2017): Humility Is the New Smart Rethinking Human Excellence in the Smart Machine Age. Berrett-Koehler Publishers Inc., Oakland.

Jeong, B. - Kejak, M. - Vinogradov, V. (2008): Changing composition of human capital: Czech Republic, Hungary and Poland. Economics of Transition, 16 (2), 247-271.

Karoliny M.-né (2017): Áttekintés az emberi erőforrás menedzsmentről. In: Karoliny M.-né - Poór, J. (szerk.): Emberi erőforrás menedzsment kézikönyv. Wolters Kluwer, Budapest.

Keszthelyi, C. (2016): Hungary suffers labor shortage in many sectors. Budapest Business Journal, September 2-September 15, 15.

Koncz, K. (2004): Kompetencia alapú személyügyi tervezés. In: Tóthné Sikora Gizella (szerk.): Humán erőforrások gazdaságtana. Bíbor Kiadó, Miskolc.

Kornai, J. (2008): A kapitalizmus néhány rendszerspecifikus vonása. Közgazdasági Szemle, LV. (5), 377-394.

Mathis, J. V.- Meglich, V. (2014): Human Resource Management. Cengage Learning, New York.

Poór, J. - Karoliny, M-né (szerk.) (2013): Emberi erőforrás kézikönyve. Complex Kiadó, Budapest.

Poór, J. - Juhász, T. - Csapó, I. - Tóth, K. - Némethy, K. (2017): Szakemberhiány és munkaerő-megtartás kulcsmunkakörökben 2017. Szent István Egyetem, Menedzsment és HR Kutató Központ, Gödöllő.

Poór, J. - Kovács, Á. - Kolbe, T. - Csapó, I. (2018): Szakemberhiány és munkaerő-megtartás kulcsmunkakörökben 2018. Szent István Egyetem, Menedzsment és HR Kutató Központ, Gödöllő.

Redman, W. (2006): Contemporary Human Resourse Management. Prentice Hall, Harlow.

Richardson, S. (2007): What is a skill shortage? Australia, National Intitute of Labour Studies.

Sajtos, L. - Mitev, A. (2007): SPSS kutatási és adatelemzési közikönyv. Alinea Kiadó, Budapest.

Saridakis, G. - Cary, L. C.: Research Handbook on Employee Turnover. Edward Elgar Publishing Limited, Northampton.

Sebők, M. (2017): Munkaerőhiány és a munkaerő-mobilitás empirikus kutatása. Tudásmenedzsment, 18 (2), 55-64.

Smith, A. (2016): Public Predictions for the Future of Workforce Automation. March 10, www.pewinternet.org (Letöltve: 2017.06.30.) 
www. metszetek.unideb.hu

\section{TEMATIKUS TANULMÁNYOK - A munkaerőpiac gazdasági-társadalmi kérdései}

Smith, M. (2014), Which jobs will see robots doing in the future? Telegraph. https:// www.telegraph.co.uk/technology/news/10805058/Which-jobs-will-we-seerobots-doing-in-the-future.html (Letöltve: 2018.01.11.)

Torrington, D. - Hall, L. - Taylor, S. (2014): Human Resource Management. Pearson Education Limited, Harlow.

Ulrich, D. (2015): Editorial: The future targets or outcomes of HR work: individuals, organizations and leadership. Human Resource Development International, 17 (1), 1-9. 